\title{
AN ANNOTATED CHECKLIST OF THE FAMILY Diaptomidae Sars, 1903 (Copepoda, Calanoida) IN VIETNAM
}

\author{
Tran Duc Luong*, Dang Ngọc Thanh, Ho Thanh Hai \\ Institute of Ecology and Biological Resources, VAST
}

\begin{abstract}
The paper presents an updated checklist of Diaptomidae in Vietnam, based on literature reviews and on our own data from voucher specimens deposited in the Institute of Ecology and Biological Resources (IEBR), Hanoi. Taxonomic status of diaptomid species occurring in the country is revised. A total of 13 genera and 29 species have been recorded; of those 29 species, 8 are endemic, and other 8 are newly added to the latest fauna list in 2001. Remarks on nomenclature and taxonomic issues are supplemented with information on the geographical distribution of the species within and outside Vietnam.

Keywords: Diaptomidae, Freshwater copepods, Vietnam.
\end{abstract}

Citation: Tran Duc Luong, Dang Ngoc Thanh, Ho Thanh Hai, 2016. An annotated checklist of the family Diaptomidae Sars, 1903 (Copepoda, Calanoida) in Vietnam. Tap chi Sinh hoc, 38(3): 384-400. DOI: 10.15625/0866-7160/v38n3.8515.

*Corresponding author: tranducluongiebr@gmail.com.

\section{INTRODUCTION}

Diaptomidae Sars, 1903 is the most speciesrich and widespread calanoid family in the continental waters. They occur in almost all types of the water bodies and wetlands, especially in the plankton of lakes, ponds and rivers. The family contains more than 440 named species allocated in 4 subfamilies and 60 genera [3]. Diaptomid copepods are dominant components of the inland water plankton in Europe, Asia, North America, Africa and at northern low-latitudes in South America. However, they do not occur in New Zealand and New Caledonia, and are rare in Australia [3]. Many diaptomid species have narrow geographical distribution which render these crustaceans highly informative in historical zoogeographic analyses.

In Southeast Asia, this family has been studied well in Thailand (32 species) [16, 27, 34, 35, 37, 40, 41, 42, 43], and Indonesia (17 species) $[1,7,8,18,21,22]$. However, it is poorly known from Malaysia (10 species) [23, 24, 25, 29], and Philippines (6 species) [8, 28, $36,60]$.

As for the diaptomid fauna in Vietnam, a few studies have been published in the second half of the last century [50, 59]. Dang et al.
(1980) [51] described the diagnostic characteristics and geographical distribution of 11 species, including a new genus and a new species, Vietodiaptomus hatinhensis. This work can be considered as the first publication of the systematics of Diaptomidae in North Vietnam. Subsequently Dang \& Ho [52, 53, 54, 55, 56, 57] added new records of Diaptomidae from Vietnam. Dang \& Ho [52, 55, 57] described 5 new species, including 3 species from the South region, Central highlands and 2 species from underground waters in a cave, Quang Binh province, Central Vietnam. Moreover, they provided a comprehensive overview of the diaptomids in Vietnam in 2001 [56], together with diagnoses and distributional information of 21 species belonging to 8 genera. Since then, some new species have been described from Vietnam [4, 13]. The classification of several taxa has been changed, and new data are available on the geographic distribution in many species as well [19, 30].

Based on the literature data and the diaptomid material deposited in the Institute of Ecology and Biological Resources (Hanoi), we provided an updated list of the species occurring in the country. The checklist aims to provide the taxonomic status and distributional information on diaptomids in Vietnam in a comprehensive 
form. This work will hopefully enhance the understanding of diaptomids in Vietnam and promote further studies, including phylogeny, biology and ecology.

\section{MATERIALS AND METHODS}

Diaptomids were collected from various localities in Vietnam, and currently deposited in the Institute of Ecology and Biological Resources, Hanoi, Vietnam. Specimens were observed under a differential interference contrast microscope (CH40, Olympus, Japan).

Abbreviations used in the text are as follows: $\mathrm{A} 1=$ antennule; $\mathrm{P} 5=\operatorname{leg} 5$; Enp = endopod; $\operatorname{Exp}=$ exopod; IEBR = Institute of Ecology and Biological Resources, Hanoi, Vietnam.

\section{RESULTS}

Taxonomic part

Order Calanoida Sars, 1903

Family Diaptomidae Sars, 1903

Genus Allodiaptomus Kiefer, 1936

Type species: Allodiaptomus mirabilipes Kiefer, 1936

\section{Allodiaptomus mieni Dang \& Ho, 1985}

Allodiaptomus mieni Dang \& Ho, 1985: 4044, fig. 1; Dang \& Ho, 2001a: 203-204, fig. 13; Tran, 2012: 81.

Type locality: Pond at Gia Lai province, Vietnam.

Specimens examined: 3 males and 5 females (IEBR-CAL10.118), an aquaculture pond, An Giang province, VIII. 2010, coll. Tran D. L.

Ecology: Mostly occurring in rivers and aquaculture ponds.

Records from Vietnam: Central highlands, South Central coast and Mekong River delta [56].

Distribution: Only known from Vietnam.

Allodiaptomus raoi Kiefer, 1936

Allodiaptomus raoi Kiefer, 1936: 137-139, figs. 1-6; Dang \& Ho, 2001a: 204-205, fig. 14; Tran, 2012: 81 .
Allodiaptomus raoi membranigera Brehm, 1951: 100, figs. 8-11; Brehm, 1953: 252.

Allodiaptomus (Reductodiaptomus) raoiReddy, 1987: 114-119, figs. 1-30; Reddy, 1994: 41-42, figs. 182-197.

Allodiaptomus specillodactylus-Reddy, 1994: 41-42.

Type locality: Nellore, South India.

Specimens examined: 10 males and 7 females (IEBR-CAL10.106), Hau river, An Giang province, VIII. 2010, coll. Tran D. L.

Ecology: It occurs in permanent and stagnant freshwater bodies, such as rivers, aquaculture ponds; sometimes found in brackish waters.

Records from Vietnam: Dong Thap, My Tho, Long An [56]; An Giang (this study).

Distribution: Cambodia [9]; India [32]; Thailand [37].

\section{Allodiaptomus specillodactylus Shen \& Tai, 1964}

Allodiaptomus specillodactylus Shen \& Tai, 1964a: 234, figs. 26-33; Shen \& Song, 1979: 157-158, fig. 82; Dang \& Ho, 2001a: 206-207, fig. 15; Tran, 2012: 81 .

Type locality: Shuntak, South China.

Specimens examined: 4 males and 2 females (IEBR-CAL10.50), Vam Co Dong river, Long An province, X. 2010, coll. Tran D. L.

Ecology: In Vietnam, this species is found in slow-flowing water of rivers.

Records from Vietnam: Dong Thap, Long An and Tien Giang [56]; Long An (this study).

Distribution: China (Guangdong) [45, 47].

Remarks: Shen \& Tai (1964a) [47] relied primarily on three diagnostic features to separate Allodiaptomus raoi from A. specillodactylus: (1) the spinous process on the antepenulimate segment of the right A1 in male with three teeth at the tip, (2) the basis of right P5 with rectangular hyaline process on the inner margin, (3) the two-segmented endopodites in the P5 of the males. Reddy 
(1987: 130-131) [31] redescribed A. raoi from India and proposed to sink $A$. specillodactylus in the synonymy of $A$. raoi based on reasons: the hyaline process on the inner margin of the basis in the right P5 also present in A. raoi and "the slight extension of the spinous process and the two-segmented condition of the endopodite in the right P5 do not warrant specific status, particularly when the intraspecific variation is taken into account". However, the specimens collected from Vietnam fit with both species $A$. raoi sensu Reddy (1987) from India and $A$. specillodactylus from China with detailed differences by the spinous process on the right A1 and the endopodite in the right P5 in male as proposed by Shen \& Tai (1964a) [47]. Therefore, we place the Vietnamese specimens as two distinct species.

\section{Genus Dentodiaptomus Shen \& Tai, 1964}

Type species: Dentodiaptomus javanus (Grochmalicki, 1915)

Dentodiaptomus javanus (Grochmalicki, 1915)

Diaptomus javanus Grochmalicki, 1915: 229-231, taf. 7, figs. 12a-e; Brehm, 1923: 225227, figs. 4-6; Kiefer, 1933: 598-599.

Dentodiaptomus javanus-Shen \& Tai, 1964b: 444-445, figs. 7-13; Shen \& Song, 1979: 145-146, fig. 74; Sanoamuang, 1999: 219, figs. 1-5; Dang \& Ho, 2001a: 233-234, fig. 31; Tran, 2012: 81-82.

Type locality: Unknown.

Specimens examined: 24 males, 19 females (IEBR-CAL11.50), Bien Ho lake, Gia Lai province, VI. 2011, coll. Tran D. L.; 13 males, 27 females (IEBR-CAL12.41), Thac Mo lake, Binh Phuoc province, V. 2012, coll. Le H. A.

Ecology: The species is found in large freshwater bodies, such as: rivers, lakes and reservoirs.

Records from Vietnam: Central highlands, Binh Phuoc province [56]; Gia Lai province (this study).

Distribution: China (Yunnan) [45, 48]; Cambodia [9]; Thailand [37]; Indonesia [6, 22].

Genus Dolodiaptomus Shen \& Tai, 1964
Type species: Dolodiaptomus spinicaudatus Shen \& Tai, 1964

Dolodiaptomus spinicaudatus Shen \& Tai, 1964

Dolodiaptomus spinicaudatus Shen \& Tai, 1964b: 446-448, figs. 14-20; Shen \& Song, 1979: 146-148, fig. 75; Ho et al., 2008: 29-31, fig. 3; Tran, 2012: 82, pl. V, fig. 40.

Type locality: Xishuangbanna, South China.

Specimens examined: 2 males, 1 female (IEBR-CAL08.63), Day river, Ha Nam province, IV. 2011, coll. Tran D. L.

Ecology: Relatively rare in Vietnam, only found in oligosaprobic waters of Day and Red rivers in the spring [19].

Records from Vietnam: Hanoi (My Duc district) [19].

Distribution: China (Yunnan) [45, 48].

\section{Genus Eodiaptomus Kiefer, 1932}

Type species: Eodiaptomus lumholtzi (Sars G.O., 1889)

\section{Eodiaptomus draconisignivomi Brehm, 1952}

Eodiaptomus draconisignivomi Brehm, 1952: 215-216, figs. 1-2; Dang et al., 1980: 291-293, fig. 172; Reddy, 1994: 95-96, figs. 515-517; Dang \& Ho, 2001a: 217-219, fig. 22; Sanoamuang, 2001a: 567-575, figs. 2-43; Tran, 2012: 82 .

Type locality: In the environs of River Mekong, Cambodia.

Specimens examined: 8 males, 12 females (IEBR-CAL12.36), Lak lake, Dak Lak province, X. 2012, coll. Tran D. L.; 14 males, 7 females (IEBR-CAL06.18), Bach Ma stream, Thua Thien-Hue province, VI. 2012, coll. Tran D. L.

Ecology: Mostly collected from freshwaters, such as reservoirs, ponds and rivers; sometimes found among macrophytes in streams.

Records from Vietnam: Nghe An, Ha Tinh, Lam Dong, Binh Phuoc, Tien Giang [56]; Thua Thien - Hue, Dak Lak (this study).

Distribution: Cambodia [9, 32]; Thailand [38].

Genus Hadodiaptomus Brancelj, 2005 
Type species: Hadodiaptomus dumonti Brancelj, 2005

\section{Hadodiaptomus dumonti Brancelj, 2005}

Hadodiaptomus dumonti Brancelj, 2005: 57-70, figs. 1-17.

Type locality: Dang Water Cave, Ninh Binh, Vietnam.

Type material: Royal Museum in Brussels (Belgium) (I.G.30.112 COP 4651).

Ecology: Living in underground water bodies in cave.

Records from Vietnam: Ninh Binh (Dang cave, Cuc Phuong National Park) (Brancelj, 2005) [4].

Distribution: Only known from Vietnam.

\section{Genus Heliodiaptomus Kiefer, 1932}

Type species: Heliodiaptomus viduus (Gurney, 1916)

\section{Heliodiaptomus elegans Kiefer, 1935}

Heliodiaptomus elegans Kiefer, 1935: 9193, figs. 6-10; Brehm, 1953: 33; Dussart \& Defaye, 1983: 97; Reddy, 1994: 16-18, figs. 7883; Reddy \& Dumont, 1999: 145-152, figs. 138; Tran, 2012: 82.

Heliodiaptomus elegans barbata Brehm, 1951: 104-105, fig. 18-19.

Heliodiaptomus serratus Shen \& Tai, 1962: 110-112, figs. 20-26; Shen \& Song, 1979: 115116, fig. 57; Dang et al., 1980: 295-296, fig. 174; Dang \& Ho, 2001a: 221-222, fig. 24; synonymized by Reddy \& Dumont (1999: 145).

Type locality: Pond near Rangoon, Myanmar.

Specimens examined: 11 males, 5 females (IEBR-CAL10.48), river in Trang An, Ninh Binh province, V. 2010, coll. Tran D. L.; 9 males, 12 females (IEBR-CAL12.54), Da river, Hoa Binh province, VII. 2012, coll. Tran D. L.

Ecology: It lives in lakes, ponds and river deltas and hilly areas.

Records from Vietnam: Red River delta and Mekong River delta [56].

Distribution: Cambodia [9]; Myanmar [32]; China [45, 46]; Bangladesh [33].
Remarks: Reddy \& Dumont (1999) [33] redescribed $H$. elegans Kiefer, 1935 and proposed to sink $H$. serratus Shen \& Tai, 1962 in the synonymy of $H$. elegans. The species was recorded in Vietnam as a species, Heliodiaptomus serratus Shen \& Tai, 1962 (Dang \& Ho, 2001a) [56].

\section{Heliodiaptomus falxus Shen \& Tai, 1964}

Heliodiaptomus falxus Shen \& Tai, 1964a: 232-233, figs. 19-25; Shen \& Song, 1979: 116117, fig. 58; Dang et al., 1980: 293-295, fig. 173; Dussart \& Defaye, 1983: 98; Reddy, 1994: 21-22, figs. 97-103; Dang \& Ho, 2001a: 219220, fig. 23; Tran, 2012: 82.

Type locality: Shuntak, South China.

Specimens examined: 17 males, 31 females (IEBR-CAL15.78), Nhue river, Ha Noi, V. 2015, coll. Nguyen T. C.

Ecology: Mostly collected from river deltas.

Records from Vietnam: Red River delta [56].

Distribution: China (Guangdong) [45, 47].

\section{Genus Mongolodiaptomus Kiefer, 1937}

Type species: Mongolodiaptomus birulai (Rylov, 1922)

\section{Mongolodiaptomus birulai (Rylov, 1923)}

Diaptomus birulai Rylov, 1923: 63, pl. 1, figs. 4-8; Brehm, 1930: 146, figs. 7-8.

Mongolodiaptomus formosanus Kiefer, 1937: 58-67, figs. 1-6; Shen \& Tai, 1962: 105107, figs. 1-7; Dang et al., 1980: 296-298: fig. 175.

Mongolodiaptomus birulai-Lai \& Fernando, 1979: 234-239, figs. 61-73; Shen \& Song, 1979: 95-96, fig. 44; Reddy et al., 2000: 108; Dang \& Ho, 2001a: 222-224, fig. 25; Tran, 2012: 83.

Type locality: Unknown.

Specimens examined: 35 males, 18 females (IEBR-CAL08.68), Cau river, Bac Giang province, V. 2008, coll. Tran D. L.; 12 males, 16 females (IEBR-CAL11.49), a pond in Kbang, Gia Lai province, VI. 2011, coll. Tran D. L.

Ecology: It occurs in clear or turbid waters in wide variety of habitats, such as aquaculture 
ponds, lakes, reservoirs and river deltas, hilly and mountainous areas.

Records from Vietnam: All provinces (Dang \& Ho, 2001a) [56].

Distribution: China (Guangdong, Guangxi, Yunnan, Fujian, Hunan, Zhejiang, Jiangsu, Hubei) [45]; Philippines [28].

Remarks: Shen \& Song (1979) [45] and Dang \& Ho (2001a) [56] considered $M$. formosanus Kiefer, 1937 as a junior synonym of Mongolodiaptomus birulai (Rylov, 1923) while Lai et al. (1979) [28] and Reddy et al. (2000) [35] listed them as two distinct species.

\section{Mongolodiaptomus botulifer (Kiefer, 1974)}

Neodiaptomus botulifer Kiefer, 1974: 420424, figs. 1-13; Lai \& Fernando, 1978a: 230232, figs. 1-11; Lai \& Fernando, 1978b: 118119, figs. 22-27; Lai \& Fernando, 1980: 53-54; Boonsom, 1984: 227; Lim \& Fernando, 1985: 85; Reddy, 1994: 64-67, figs. 357-369; Reddy et al., 1998: 201-208, figs. 1-36; Dang \& Ho, 2001a: 230-231, fig. 29.

Diaptomus visnu Daday, 1906: 200-201, pl. 16, figs. 17-20; Tollinger, 1911: 32-33, figs. S; Brehm, 1954: 418.

?Heliodiaptomus visnu-Kiefer, 1932: 474.

Neodiaptomus malaindosinensis Lai \& Fernando, 1978a: 232-234: figs. 12-29; Lai \& Fernando, 1981: 164-165, figs. 77-79; Reddy, 1994: 54-56, figs. 286-303; synonymized by Reddy et al. (1998: 208).

Mongolodiaptomus botulifer-Reddy et al., 2000: 108; Tran, 2012: 83.

Type locality: A fish pond at Butterworth, Penang, Malaysia.

Specimens examined: 22 males, 19 females (IEBR-CAL05.24), Tra Khuc river, Quang Ngai, IV. 2005, coll. Le H. A.; 24 males, 36 females (IEBR-CAL09.31), a pond, Kien Giang province, XII. 2009, coll. Tran D. L.

Ecology: This species has been found in various freshwaters bodies, such as aquaculture ponds, reservoirs, lakes and rivers, and especially favors the stagnant and eutrophic waters.

Records from Vietnam: Lam Dong, Binh
Thuan, Binh Phuoc and Mekong River delta [56]; Quang Ngai, Kien Giang (this study).

Distribution: Cambodia; Thailand; Malaysia; Singapore [32, 34].

Remarks: Daday (1906) [12] described Diaptomus visnu from Singapore. He reported that the same diaptomid had occurred in the Botanical Garden, Sai Gon, Vietnam, but he did not give any details of the female, and the description of the male is not detailed enough to enable accurate species diagnosis [23].

Neodiaptomus botulifer was originally described from Butterworth (Northwest Malaysia) by Kiefer (1974) [20]. It was redescribed by Lai \& Fernando (1978a) [23] and Reddy et al. (1998) [34]. Reddy et al. (2000) [35] amended delimitation of Mongolodiaptomus and transferred Neodiaptomus botulifer to the genus Mongolodiaptomus. Reddy et al. (1998) [34] proposed to sink Neodiaptomus malaindosinensis Lai \& Fernando, 1978 in the synonymy of $M$. botulifer.

Based on the original descriptions of Daday (1906) [12] and Kiefer (1974) [20], the redescription of Lai \& Fernando (1978a) [23] and the SEM pictures provided by Reddy et al. (2000) [35], we consider the diaptomids under the name Diaptomus visnu, Phyllodiaptomus (?) visnu, Neodiaptomus visnu, Neodiaptomus botulifer to be conspecific, with the valid name Mongolodiaptomus botulifer (Kiefer, 1974).

Based on careful examination of the specimens collected in 2007, 2008 from South Vietnam, we record Mongolodiaptomus botulifer (Kiefer, 1974) with common occurence in the freshwater bodies in South Vietnam (Ninh Thuan, Kon Tum, Gia Lai, Ca Mau and Sai Gon).

\section{Mongolodiaptomus calcarus (Shen \& Tai, 1965)}

Allodiaptomus calcarus Shen \& Tai, 1965: 126-128, figs. 1-7; Shen \& Song, 1979: 155156, fig. 80; Dang et al., 1980: 287-288, fig. 170; Dussart \& Defaye, 1983: 100; Reddy, 1994: 38-39, figs. 170-176; Reddy et al., 1998: 213-220, figs. 64-94; Dang \& Ho, 2001a: 210212, fig. 18 . 
Neodiaptomus mephistopheles-Lai \& Fernando, 1978b: 119-120, figs 28-34; Bricker et al., 1978: 1-14; Lai \& Fernando, 1980: 53; Lai \& Fernando, 1981: 165, figs. 73-76; Boonsom, 1984: 227; Lai, 1986: 43.

Mongolodiaptomus calcarus-Reddy et al., 2000: 108; Tran, 2012: 83.

Type locality: A pond at Kweihsien, Guangxi province, South China.

Specimens examined: 6 males, 12 females (IEBR-CAL08.73), Pa Khoang lake, Dien Bien province, VI. 2008, coll. Tran D. L.; 13 males, 4 females (IEBR-CAL10.24), Da river, Hoa Binh, IV. 2010, coll. Tran D. L.

Ecology: It is found in temporary (aquaculture ponds) or permanent water bodies, such as lakes and rives.

Records from Vietnam: Northeast and Northwest areas [56].

Distribution: China (Guangdong, Guangxi) [45]; Thailand; Malaysia; Indonesia [34].

Remarks: Although Reddy et al. (2000) [35] reallocated this species to the genus Mongolodiaptomus, Dang \& Ho (2001a) [56] referred to this species as Allodiaptomus calcarus Shen \& Tai, 1965.

\section{Mongolodiaptomus gladiolus (Shen \& Lee, 1963)}

Allodiaptomus gladiolus Shen \& Lee, 1963: 587-588, figs. 46-51; Shen \& Song, 1979: 156157, fig. 81; Dang et al., 1980: 286-287: fig. 169; Dussart \& Defaye, 1983: 99; Reddy, 1994: 36-37, figs. 164-169; Dang \& Ho, 2001a: 212213, fig. 19.

Mongolodiaptomus gladiolus-Reddy et al., 2000: 108; Tran, 2012: 83.

Type locality: "Freshwater regions of the Chiekong River and the Delta of the Pearl River (Canton), China" [32].

Specimens examined: 7 males, 16 females (IEBR-CAL09.44), Cau river, Bac Giang province, VIII. 2009, coll. Tran D. L.; 17 males, 6 females (IEBR-CAL11.16), a fish pond, Hai Duong province, III. 2011, coll. Tran D. L.

Ecology: Mainly inhabiting aquaculture ponds and rivers in delta area.
Records from Vietnam: Hai Duong, Hung Yen [56], Bac Giang, Hai Duong (this study).

Distribution: China (Guangdong) [32, 45].

Remarks: Although Reddy et al. (2000) [35] reallocated this species to the genus Mongolodiaptomus, Dang \& Ho (2001a) [56] referred to this species as Allodiaptomus gladiolus Shen \& Lee, 1963.

\section{Mongolodiaptomus pectinidactylus (Shen \& Tai, 1964)}

Allodiaptomus pectinidactylus Shen \& Tai, 1964a: 234-235, figs. 26-33; Shen \& Song, 1979: 158-159, fig. 83; Dang et al., 1980; 284286, fig. 168; Dussart \& Defaye, 1983: 99; Reddy, 1994: 39-40, figs. 177-181; Dang \& Ho, 2001a: 207-208, fig. 16.

Mongolodiaptomus pectinidactylus-Reddy et al., 2000: 108; Tran, 2012: 83-84.

Type locality: Man-ning, Hainan Island, South China.

Specimens examined: 4 males, 5 females (IEBR-CAL10.26), Day river, Ha Nam province, III. 2010, coll. Tran D. L.

Ecology: Mainly inhabiting fish ponds and rivers in delta area. [56].

Records from Vietnam: Red River delta

Distribution: China (Hainan Island) [47].

Remarks: Although Reddy et al. (2000) [35] reallocated this species to the genus Mongolodiaptomus, Dang \& Ho (2001a) [56] referred to this species as Allodiaptomus pectinidactylus Shen \& Tai, 1964.

\section{Mongolodiaptomus sp.1}

Mongolodiaptomus sp.1 Tran, 2012: 84, pl. $\mathrm{V}$, figs. 43-44.

Specimens examined: 20 males, 12 females (IEBR-CAL11.48), Bien Ho lake, Gia Lai province, VI. 2011, coll. Tran D. L.

Ecology: Found in lakes.

Records from Vietnam: Gia Lai (Bien Ho lake).

Extralimital distribution: Unknown.

Remarks: Mongolodiaptomus sp. 1 is a 
member of the genus Mongolodiaptomus sensu Kiefer, 1938 and Reddy et al., 2000 because of: (1) the second and third urosomites of the male bearing setules on the right ventral margin; (2) the right caudal ramus in male with chitinous knob on the ventral side; (3) spine is present on 16 th segment of the right antennule in male; (4) the male P5 has large and chitinous plate on the inner coxal segment; (5) Exp-2 of right P5 in male with a principal spine inserting in halfway of the lateral margin and a small spinous process occurring distally.

Only ten Mongolodiaptomus species have been known in the world (Reddy et al., 2000; Sanoamuang, 2001c) [35, 40]. Mongolodiaptomus sp.1 is very similar to M. birulai (Rylov, 1923) which is distributed in China [45], Philippines [28] and Vietnam [56], in the structure of P5 in the male, and lateral wings of the fifth pediger and the genital somite in the female. This species, however, can be distinguished from $M$. birulai by the comb-like spinous process on antepenultimate segment of right antennule in male (versus with rod-like process on antepenultimate segment in $M$. birulai). Most likely it is a new species or a subspecies of $M$. birulai, but a more detailed analysis of the morphological characteristics is needed to support our hypothesis.

\section{Mongolodiaptomus sp.2}

Mongolodiaptomus sp.2 Tran, 2012: 84, pl. $\mathrm{V}$, figs. 45-46.

Specimens examined: 35 males, 22 females (IEBR-CAL08.25), lake and stream in Nui Chua National Park, Ninh Thuan province, XI. 2008, coll. Tran D. L.

Ecology: It occurs in lakes and streams.

Records from Vietnam: Ninh Thuan province.

\section{Extralimital distribution: Unknown.}

Remarks: Like Mongolodiaptomus sp.1, this species fits the generic diagnosis of Mongolodiaptomus given in Kiefer (1938) and Reddy et al. (2000) [35]. The comb-like spinous process on the antepenultimate segment of right antennule present in the male of Mongolodiaptomus sp.2 is only shared with three species in the genus, M. uenoi (Thailand, Indonesia, China, Vietnam) M. dumonti (Thailand) and M. calcarus (China, Vietnam). Our species clearly differs from the species mentioned above in the structure of leg 5 in male. Mongolodiaptomus sp. 2 is more closely related to $M$. birulai, $M$. sp. 1 and Allodiaptomus mieni as they have similar morphology of P5 in male. Mongolodiaptomus sp.2 can be distinguished from the congeners by the following details of P5 in male: (1) Enp segment of right P5 is sturdy and large coneshaped (smaller and triangular in M. birulai and M. sp.1); (2) basis of right P5 with a prominent spur-like process on the middle of posterior surface (absent in M. birulai, M. sp. 1 and $A$. mieni); (3) rectangular shape of hyaline lobe on middle of inner margin (semicircular shape in A. mieni); (4) principal lateral spine Exp-2 extending beyond the distal border of the segment (only reaching to distal border of Exp2 segment in M. birulai, M. sp. 1 and A. mieni) and (5) distal spine of Exp-2 large, triangular (vs. small, conical shape protrusion is present in $M$. birulai and $M$. sp.1, while the distal spine is absent in A. mieni). Mongolodiaptomus sp.2 very likely represents a new species, nevertheless we need more detailed morphological examinations to substantiate its taxonomic status.

\section{Mongolodiaptomus uenoi (Kikuchi, 1936)}

Diaptomus uenoi Kikuchi, 1936: 198-200, figs. 1-6.

Allodiaptomus rappeportae-Dang \& $\mathrm{Ho}$, 1994; Dang \& Ho, 2001a: 17-18: fig. 17; Dang \& Ho, 2002: 278-280, fig. 4.

Allodiaptomus uenoi-Shen \& Song, 1979: 153-155, fig. 79.

Neodiaptomus uenoi-Lai \& Fernando, 1980: 56-57, fig. 3; Lai, 1986: 43-45, figs. 10-15.

Mongolodiaptomus uenoi-Kiefer, 1938: 56; Dussart \& Defaye, 1983: 104; Reddy et al., 2000: 99-109, figs. 1-32; Tran, 2012: 84-85. China.

Type locality: Kosyun, Southern Formosa,

Specimens examined: 38 males, 22 females (IEBR-CAL10.36), a fish pond, Sa Thay, Kon 
Tum, VI. 2010, coll. Tran D. L.; 7 males, 2 females (IEBR-CAL12.39), Serepok river, Dak Lak province, X. 2012, coll. Tran D. L.

Ecology: Wide variety of habitats such as fish ponds, reservoirs, lakes and rivers.

Records from Vietnam: Quang Nam, Gia Lai, Kon Tum, Can Tho provinces [56]; Dak Lak (this study).

Distribution: Thailand [35]; Indonesia [26]; Taiwan (China) [45].

Remarks: Dang \& Ho (1994, 2001a) [54, 56] recorded the species Allodiaptomus rappeportae (Brehm, 1923) from Phu Ninh reservoir (Quang Nam), Kon Tum and Can Tho provinces. The description and illustration of $A$. rappeportae by Dang \& Ho (1994, 2001a) [54, 56] nonetheless fit the original description of Diaptomus uenoi Kikuchi, 1936 from Taiwan. Reddy et al. (2000) [35] redescribed D. uenoi and transferred it to Mongolodiaptomus. We identified the specimens collected in 2008, 2009 from Kon Tum and Gia Lai provinces, as Mongolodiaptomus uenoi (Kikuchi, 1936); their morphology completely fits the description of "Allodiaptomus rappeportae" by Dang \& Ho (1994, 2001a) [54, 56]. For the reasons mentioned above, we propose to remove Diaptomus rappeportae Brehm, 1923 (= Allodiaptomus rappeportae, = ?Phyllodiaptomus rappeportae) from the list of diaptomid copepods of Vietnam, instead here we record Mongolodiaptomus uenoi (Kikuchi, 1936) with native distribution in the South Central coast, Central highlands and Mekong River delta regions.

\section{Genus Nannodiaptomus Dang \& Ho, 2001}

Type species: Nannodiaptomus phongnhaensis Dang \& Ho, 2001

Nannodiaptomus phongnhaensis Dang \& Ho, 2001

Nannodiaptomus phongnhaensis Dang \& Ho, 2001b: 1-2, fig. 1; Tran, 2012: 85.

Type locality: River in Phong Nha cave, Quang Binh province, Vietnam.

Specimens examined: 26 males, 38 females (IEBR-COP-AED04.14.021), a siphon lake, Va cave, Quang Binh province, IV. 2014, coll. Tran D. L.

Ecology: This species was found in siphon lakes, temporary pools and underground rivers in karst cave.

Records from Vietnam: Quang Binh (Phong Nha-Ke Bang) [57].

Distribution: Only known from Vietnam.

\section{Genus Neodiaptomus Kiefer, 1932}

Type species: Neodiaptomus schmackeri (Poppe \& Richard, 1892)

Neodiaptomus curvispinosus Dang \& Ho, 2001

Neodiaptomus curvispinosus Dang \& Ho, 2001b: 2-3, fig. 2; Tran, 2012: 85.

Type locality: River in Phong Nha cave, Quang Binh province, Vietnam.

Specimens examined: 30 males, 50 females (IEBR-CAL09.35), stream near Bay Tang cave, Phong Nha-Ke Bang, VIII. 2009, coll. Nguyen D. T.; 25 males, 25 females (IEBR-CAL13.23), a pond inside Son Doong cave, Phong Nha-Ke Bang, Quang Binh province, IV. 2013, coll. Tran D. L.

Ecology: Living in temporary pools, underground rivers and the streams of karstic mountainous areas.

Records from Vietnam: Quang Binh (Phong Nha-Ke Bang) [57].

Distribution: Only known from Vietnam.

\section{Neodiaptomus schmackeri (Poppe \& Richard, 1892)}

Diaptomus schmackeri Poppe \& Richard, 1892: 149-151, figs. 1-6; Kiefer, 1928: 106-109, figs. 20-22; Brehm, 1930: 154.

Neodiaptomus schmackeri-Kiefer, 1932: 475, 509, fig. 87; Kiefer, 1939: 121-126, figs. 11-12; Brehm, 1953: 258-263; Rajendran, 1971: 92-99, figs. 1-2; Shen \& Song, 1979: 139-141, fig. 71; Lai \& Fernando, 1981: 165, figs. 24-35; Chang \& Kim, 1986: 55-56; Borutzky et al., 1991: 426-427, fig. 189; Reddy \& Reddy S., 1992: 125, fig. 1; Reddy, 1994: 46-48, figs. 198-215; Chang, 2009: 130-135, figs. 37-39; Tran, 2012: 85 . 
Diaptomus strigilipes-Gurney, 1907: 30-31, pl. 2, figs. 18-20.

Neodiaptomus strigilipes-Kiefer, 1932: 475 , 509; Brehm, 1953: 258-263, figs. 20-23; Dumont \& Van de Velde, 1977: 62, fig. 10; Reddy \& Radhakrishna, 1984: 28; Dussart \& Fernando, 1985: 232-233, figs. 15-21.

Diaptomus handeli-Brehm, 1921: 194-195; Rylov, 1925: 313-314, figs. 8-13.

Neodiaptomus handeli-Kiefer, 1932: 475, 509; Mashiko, 1951: 144-145, fig. 3; Brehm, 1953: 258-263; Shen \& Tai, 1962: 102-103; Shen \& Sung, 1965: 167-168; Uéno, 1966: 105107, figs. 49-59; Lai \& Fernando, 1978b: 113115, figs. 1-8; Dang et al., 1980; 301-304, fig. 177; Dang \& Ho, 2001a: 226-228, fig. 27.

Neodiaptomus bisegmentus $\mathrm{Hu}, 1943: 115-$ 118, figs. A, 1-7.

Type locality: Lake Tahoo, China.

Specimens examined: 31 males, 36 females (IEBR-CAL06.32), a fish pond, Nghia Dan district, Nghe An province, III. 2006, coll. Tran D. L; 20 males, 20 females (IEBR-CAL12.66), a pond, Viet Tri, Phu Tho province, IX. 2012, coll. Tran D. L.

Ecology: It occurs in clear or turbid waters in wide variety of habitats, such as aquaculture ponds, lakes, reservoirs and river deltas, hilly and mountainous areas.

Records from Vietnam: Hai Duong, Bac Giang [56]; Nghe An, Phu Tho (this study).

Distribution: Thailand; Malaysia; Singapore; Philippines; China; India; Sri Lanka; Nepal; South Korea [11, 32].

Remarks: Dang \& Ho (2001a) [56] recorded this species as Neodiaptomus handeli (Brehm, 1921) with native distribution in Hai Duong, Bac Giang provinces (Vietnam) and South of China (China). Shen \& Song (1979) [45] considered N. handeli (Brehm, 1921) as a junior synonym of N. schmackeri (Poppe \& Richard, 1892). This opinion is widely accepted (see Reddy (1994); Dussart \& Defaye (2002); Chang (2009)) [11, 17, 32].

Neodiaptomus vietnamensis Dang \& Ho, 1998

Neodiaptomus vietnamensis Dang \& Ho,
1998: 1-6, fig. 3; Dang \& Ho, 2001a: 228-229, fig. 28; Tran, 2012: 85 .

Neodiaptomus visnu (non Diaptomus visnu Daday, 1906)-Dang \& Pham, 1979: 1-4.

Type locality: Pond at Hoa Thang, Buon Ma Thuot, Dak Lak, Vietnam.

Specimens examined: 12 males, 6 females (IEBR-CAL09.18), Dong Nai river, Bien Hoa, VI. 2009, coll. Tran D. L.; 8 males, 18 females (IEBR-CAL10.39), a pond, Sa Thay, Kon Tum province, VI. 2010, coll. Tran D. L.

Ecology: Aquaculture ponds, lakes and river deltas, hilly and mountainous areas.

Records from Vietnam: Central highlands, Mekong River delta [56].

Distribution: Only known from Vietnam.

\section{Neodiaptomus yangtsekiangensis Mashiko, 1951}

Neodiaptomus yangtsekiangensis Mashiko, 1951: 10-11, fig. 4; Shen \& Tai, 1962: 103-04; Shen \& Sung, 1965: 178; Shen \& Song, 1979: 141-143, fig. 72; Dang et al., 1980: 299-301, fig. 176; Dussart \& Defaye, 1983: 95; Borutzky et al., 1991: 428, fig. 190; Reddy, 1994: 60-62, figs. 319-326; Reddy et al., 1998: 208-212, figs. 37-63; Dang \& Ho, 2001a: 224-226, fig. 26; Tran, 2012: 85-86.

Type locality: The Yangtsekiang river at Hankow, Central China.

Specimens examined: 5 males, 14 females (IEBR-CAL06.37), Ca river, Nghe An province, III. 2006, coll. Tran D. L.; 25 males, 25 females (IEBR-CAL06.22), a fish pond, Phu Loc, Thua Thien-Hue, VI. 2006, coll. Tran D. L.

Ecology: Aquaculture ponds, lakes and rivers. It is also found in brackish estuaries.

Records from Vietnam: Bac Kan, Thai Nguyen, Hai Duong, Hung Yen, Nghe An [56], Thua Thien-Hue (this study).

Distribution: Thailand [34]; China (Guangdong, Guangxi, Hubei, Jiangsu, Anhui) [45].

\section{Genus Phyllodiaptomus Kiefer, 1936}

Type species: Phyllodiaptomus blanci (Guerne \& Richard, 1896) 


\section{Phyllodiaptomus tunguidus Shen \& Tai, 1964}

Phyllodiaptomus tunguidus Shen \& Tai, 1964a: 235-237, figs. 34-42; Shen \& Song, 1979: 148-149, fig. 76; Dussart \& Defaye, 1983: 93; Reddy \& Venkateswarlu, 1989: 142; Dang \& Ho, 1991: 31-32, fig. 1-5; Dumont \& Reddy, 1993: 81-86, figs. 69-118; Reddy, 1994: 82-85, figs. 455-463; Dang \& Ho, 2001a: 231233, fig. 30; Tran, 2012: 86.

Type locality: Shuntak, South China.

Specimens examined: 15 males, 15 females (IEBR-CAL10.41), Day river, Ninh Binh, VI. 2010, coll. Nguen D. T.; 13 males, 8 females (IEBR-CAL12.70), a pond, Viet Tri, Phu Tho, XII. 2012, coll. Tran D. L.; 7 males, 31 femlaes (IEBR-CAL15.93), Ma river, Thanh Hoa province, IV. 2015, coll. Nguyen T. C.

Ecology: Wide variety of habitats, such as aquaculture ponds, reservoirs, lakes and rivers. [56].

Records from Vietnam: Northern Vietnam

Distribution: China (Guangdong, Yunan, Guangxi) [32, 45].

\section{Genus Sinodiaptomus Kiefer, 1932}

Type species: Sinodiaptomus chaffanjoni (Richard, 1897)

\section{Sinodiaptomus sarsi (Rylov, 1923)}

Diaptomus chaffanjoni var. sarsi Rylov, 1923: 71-73, pl. 2, figs. 13-18.

Diaptomus chaffanjoni (non Richard, 1897)Sars, 1903: 17-19, fig. 1; Kikuchi, 1928: 71, pls. 19-20, figs. 21-28.

Diaptomus sarsi-Kiefer, 1928: 104, figs. 1619; Rylov, 1930: 191, fig. 62.

Sinodiaptomus sarsi-Kiefer, 1932: 472, 509, fig. 88; Kiefer, 1937: 293; Kiefer, 1938: 256, figs. 6-9; Kikuchi, 1940: 291, fig. 4; Borutzky, 1959: 47; Chen, 1963: 1, pls. 1-2, figs. 1-19; Kiefer, 1978: 157-158: pl. 70; Shen \& Song, 1979: 121, fig. 61; Ho et al., 2008: 27-29, figs. 1-2; Chang, 2009: 124-127, fig. 33; Tran, 2012: 86, pl.V, fig. 39.

Sinodiaptomus (Sinodiaptomus) sarsiDussart \& Defaye, 1983: 100; Borutzky, 1991: 420-422, fig. 187A.
Sinodiaptomus (Sinodiaptomus) sarsi sarsiReddy, 1994: 198-201, figs. 1065-1067, 10821091; Dussart \& Defaye, 2002: 124. 1986.

Sinodiaptomus monrovia Streletskaya,

Type locality: Harbin (Heilongjiang province), China.

Specimens examined: 2 males, 2 females (IEBR-CAL08.70), Day river, Ha Nam province, IV. 2008, coll. Tran D. L.

Ecology: This species is relatively rare in Vietnam, only found in oligosaprobic water of Day river in the spring [19].

Records from Vietnam: Ha Noi, Ha Nam [19].

Distribution: China; Korea; Mongolia; Japan; Iran; Azerbaijan; Russia [32].

\section{Genus Tropodiaptomus Kiefer, 1932}

Type species: Tropodiaptomus orientalis (Brady, 1886)

\section{Tropodiaptomus foresti Defaye, 2002}

Tropodiaptomus foresti Defaye, 2002: 341350, figs. 1-3.

Type locality: Pond surrounded by temporary water, near Nha Trang, Khanh Hoa province, Vietnam.

Type material: Muséum national d'Histoire naturelle, Paris (MNHN-Cp1916).

Ecology: This species was found in a pond with temporary water, near Nha Trang city (Defaye, 2002) [13].

Records from Vietnam: Khanh Hoa (near Nha Trang city) [13].

Distribution: Only known from Vietnam.

\section{Tropodiaptomus oryzanus Kiefer, 1937}

Tropodiaptomus oryzanus Kiefer, 1937: 6364, figs. 12-16; Kiefer, 1938: 37-41, figs. 1-5; Shen \& Tai, 1962: 114, figs. 27-34; Shen \& Song, 1979: 87-88, fig. 39; Dang et al., 1980: 289-291, fig. 171; Kiefer, 1982: 241, figs. 1d, 9a-k; Dang \& Ho, 2001a: 214-215, fig. 20; Chang \& Kim, 1986: 52, pl. 2, figs. 6-9; Chang, 2009: 117-120, fig. 28; Tran, 2012: 86.

Tropodiaptomus (Tropodiaptomus) oryzanus-Dussart \& Defaye, 2002: 143. 
Type locality: Unknown.

Specimens examined: 6 males, 8 females (IEBR-CAL10.21), Tuyet Son spring, Ha Noi, VIII. 2010, coll. Nguyen D. T.

Ecology: This species occurs in freshwater bodies such as streamside puddles, rivers and lakes.

Records from Vietnam: All provinces [56].

Distribution: China (Taiwan, Kiangsu, Hopei) [45]; Korea; Japan [11].

\section{Tropodiaptomus vicinus (Kiefer, 1930)}

Diaptomus vicinus Kiefer, 1930: 121, figs. 10-12; Brehm, 1930: 142, fig. 1.

Tropodiaptomus vicinus-Kiefer, 1932: 501, fig. 57a; Kiefer, 1933: 540, figs. 18-25; Brehm, 1953: 291-292, figs. 54-56; Lai \& Fernando, 1979: 229, figs. 22-28; Kiefer, 1982: 232-235, figs. 1k, 4a-k; Sanoamuang, 1999: 219, figs. 611; Dang \& Ho, 2001a: 215-217, fig. 21; Tran, 2012: 86 .

Type locality: Rice fields at Singkarak, Sumatra, Indonesia.

Specimens examined: 17 males, 12 females (IEBR-CAL12.28), Konlok lake, Kon Ka King, Kon Tum, II. 2012, coll. Tran D. L.

Ecology: Mainly inhabiting large permanent bodies, such as lakes, reservoirs and rivers.

Records from Vietnam: Central highlands, Mekong River delta [56].

Distribution: Indonesia [22]; India [10]; Malaysia [25]; Thailand [37].

\section{Genus Vietodiaptomus Dang, 1977}

Type species: Vietodiaptomus hatinhensis Dang, 1977.

\section{Vietodiaptomus hatinhensis Dang, 1977}

Vietodiaptomus hatinhensis Dang, 1977: 97, fig. 1; Dang et al., 1980: 281-284, fig. 167; Dang \& Ho, 2001a: 199-200, fig. 11; Dang \& Ho, 2002: 275, fig. 2; Tran, 2012: 87.

Type locality: Boc Nguyen lake, Ha Tinh province, Vietnam.

Specimens examined: 3 males, 2 females (IEBR-CAL12.37), Bien Ho lake, Gia Lai province, X. 2012, coll. Tran D. L.; 2 males, 1 female (IEBR-CAL10.52), Han river, Da Nang,
VIII. 2010, coll. Tran D. L.

Ecology: Aquaculture ponds, lakes and rivers, sometimes found in brackish waters.

Records from Vietnam: Ha Noi, Ha Tinh, Thua Thien-Hue provinces, Central highlands, Mekong River delta [56], Gia Lai, Da Nang (this study).

Distribution: Only known from Vietnam.

\section{Vietodiaptomus tridentatus Dang \& Ho, 1985}

Vietodiaptomus tridentatus Dang \& Ho, 1985: 40-44. fig. 2; Dang \& Ho, 2001a: 201202, fig. 12; Tran, 2012: 87.

Type locality: Pond at My Tho, Tien Giang, Vietnam.

Specimens examined: 16 males, 21 females (IEBR-CAL11.51), Dakma lake, Gia Lai, VI. 2011, coll. Tran D. L.; 15 males, 15 females (IEBR-CAL09.23), Cai river, Kien Giang, XII. 2009, coll. Tran D. L.

Ecology: Living in freshwater bodies as fish ponds, lakes and rivers.

Records from Vietnam: My Tho, Tien Giang [56], Gia Lai, Kien Giang (this study).

Distribution: Only known from Vietnam.

\section{DISCUSSION}

Based on the review of the published data and examination of the diaptomid collection deposited in IEBR, we updated the list of the diaptomid copepods occurring in Vietnam (Table 1). At present, 29 species of 13 diaptomid genera are known from the inland freshwaters of our country, of which two species were only identified at genus level. The most species-rich genus is Mongolodiaptomus with 8 species, followed by Neodiaptomus (4 species), Allodiaptomus, Tropodiaptomus (3 species each), Heliodiaptomus, Vietodiaptomus (2 species), and Dentodiaptomus, Dolodiaptomus, Eodiaptomus, Hadodiaptomus, Nannodiaptomus, Phyllodiaptomus, Sinodiaptomus with one species in each. Eight species belonging to three genera are endemic to Vietnam. Eight species are newly added to the latest fauna list by Dang \& Ho, 2001a [56]. Changes in taxonomic status concerned seven species. 
Table 1. List of species and distribution of freshwater diaptomids in Vietnam

\begin{tabular}{|c|c|c|c|c|c|c|c|c|}
\hline \multirow{2}{*}{$\mathrm{N}^{0}$} & \multirow{2}{*}{ Taxon } & \multicolumn{7}{|c|}{ Geographic distribution inVietnam } \\
\hline & & I & II & III & IV & $\mathrm{V}$ & VI & VII \\
\hline 1 & Allodiaptomus mieni Dang \& Ho, 1985* & & & & & + & + & + \\
\hline 2 & A. raoi Kiefer, 1936 & & & & & & & + \\
\hline 3 & A. specillodactylus Shen \& Tai, 1964 & & & & & & & + \\
\hline 4 & Dentodiaptomus javanus (Grochmalicki, 1915) & & & & & + & + & \\
\hline 5 & Dolodiaptomus spinicaudatus Shen \& Tai, 1964 \# & & & + & & & & \\
\hline 6 & Eodiaptomus draconisignivomi Brehm, 1952 & & & & & & + & + \\
\hline 7 & Hadodiaptomus dumonti Brancelj, 2005*,\# & & & + & & & & \\
\hline 8 & Heliodiaptomus elegans Kiefer, $1935 \S$ & & & + & & & & + \\
\hline 9 & H. falxus Shen \& Tai, 1964 & & & + & & & & \\
\hline 10 & Mongolodiaptomus birulai (Rylov, 1923) & + & + & + & + & + & + & + \\
\hline 11 & M. botulifer (Kiefer, 1974) § & & & & & + & & + \\
\hline 12 & M. calcarus (Shen \& Tai, 1965) § & + & + & & & & & \\
\hline 13 & M. gladiolus (Shen \& Lee, 1963) § & & & + & & & & \\
\hline 14 & M. pectinidactylus (Shen \& Tai, 1964) § & & & + & & & & \\
\hline 15 & Mongolodiaptomus sp.1 \# & & & & & + & & \\
\hline 16 & Mongolodiaptomus sp.2 \# & & & & & & + & \\
\hline 17 & M. uenoi (Kikuchi K., 1936) § & & & & & + & & \\
\hline 18 & Nannodiaptomus phongnhaensis Dang \& Ho, 2001*, \# & & & & + & & & \\
\hline 19 & Neodiaptomus curvispinosus Dang \& Ho, 2001*,\# & & & & + & & & \\
\hline 20 & N. schmackeri (Poppe \& Richard, 1892) § & + & + & + & + & & & \\
\hline 21 & N. vietnamensis Dang \& Ho, 1998* & & & & & + & & + \\
\hline 22 & N. yangtsekiangensis Mashiko, 1951 & + & + & + & + & & & \\
\hline 23 & Phyllodiaptomus tunguidus Shen \& Tai, 1964 & + & + & + & + & & & \\
\hline 24 & Sinodiaptomus sarsi (Rylov, 1923) \# & & & + & & & & \\
\hline 25 & Tropodiaptomus foresti Defaye, 2002*, \# & & & & & & + & \\
\hline 26 & T. oryzanus Kiefer, 1937 & + & + & + & + & + & + & + \\
\hline 27 & T. vicinus (Kiefer, 1930) & & & & & + & & + \\
\hline 28 & Vietodiaptomus hatinhensis Dang, 1977* & & & & + & + & + & + \\
\hline 29 & V. tridentatus Dang \& Ho, 1985* & & & & & + & & + \\
\hline
\end{tabular}

Abbreviations and notes: I. Northeast region; II. Northwest region; III. Red River delta and North Central coast regions; IV. North Central mountains region; V. Central highlands region; VI. South Central coast; VII. Mekong River delta; * Species endemic in Vietnam; \# The species were updated to list of Dang \& Ho, 2001a; $\S$ Species with changed taxonomic status.

Distribution characteristics of north-south of diaptomids in Vietnam is remarkable. While two species, M. birulai and T. oryzanus, are widely distributed all over Vietnam, a group of species, M. calcarus, N. schmackeri, N. yangtsekiangensis and P. tunguidus are found only in northern Vietnam. Another group of diaptomid species, consisting of A. mieni, D. javanus, E. draconisignivomi, M. botulifer and $N$. vietnamensis, are distributed only in southern Vietnam. Especially, some species such as $A$. raoi and A. specillodactylus are found only in the Mekong River delta. Several species such as $N$. phongnhaensis, $H$. dumonti and $N$. curvispinosus have limited distributions in underground caves in the limestone mountains. In Vietnam, the species composition of groundwater dwelling calanoids has been poorly studied except for few records of Dang \& Ho (2001b) [57] and Brancelj (2005) [4]. Never the less, the studies show that stygobiotic diaptomids are richest in Vietnam in comparison with other countries in Southeast Asia [5]. 


\section{CONCLUSION}

The family Diaptomidae Sars, 1903 was reviewed from Vietnam based on literature and available specimens. A total of 29 species in 13 genera has been recorded in Vietnam. Of which, eight are endemic and the other eight are newly added to the previous list compiled by Dang \& Ho in 2001.

The diaptomid species is narrowly distributed because of their limitation on adaptation to various habitats in different geographical areas in Vietnam. The group is expected to have more diversity, and more new species, which are awaiting to be discovered. More extensive research is required on biogeographical distributions, ecology and phylogeny.

Acknowledgments: This research is funded by the Vietnam National Foundation for Science and Technology Development (NAFOSTED) under grant number 106-NN.05-2013.13 and the research support project for young scientists of Vietnam Academy of Science and Technology (VAST) (Project's ID: VAST.DLT.02/14-15). We would like to deeply thank Dr. Maria Hołyńska (Museum and Institute of ZoologyPolish Academy of Sciences, Warsaw, Poland) for her invaluable comments on the manuscript. Helpful comments of the reviewers are gratefully acknowledged.

\section{REFERENCES}

1. Alekseev V. R., Haffner D. G., Vaillant J. J., Yusoff F. M., 2013. Cyclopoid and calanoid copepod biodiversity in Indonesia. J. Limnol., 72(s2): 245-274.

2. Boonsom J., 1984. The freshwater zooplankton of Thailand (Rotifera and Crustacea). Hydrobiologia, 113(1): 223229.

3. Boxshall G. A., Defaye D., 2008. Global diversity of copepods (Crustacea: Copepoda) in freshwater. Hydrobiologia, 595(1): 195-207.

4. Brancelj A., 2005. Hadodiaptomus dumonti n. gen., n. sp., a new freshwater stygobitic calanoid (Crustacea: Copepoda: Calanoida) from Vietnam (South Asia) and a new member of the subfamily Speodiaptominae Borutzky, 1962. Hydrobiologia, 534(1): 5770.

5. Brancelj A., Boonyanusith C., Watiroyram S., Sanoamuang L., 2013. The groundwaterdwelling fauna of South East Asia. J. Limnol., 72(s2): 327-344.

6. Brehm V., 1923. Zur Mikrofauna javanischer Binnengewässer. Treubia, Bogor (formerly Buitenzorg), 3: 222-229.

7. Brehm V., 1933. Mitteilungen von der Wallacea-Expedition. Mitteilung IV. Einige neue Diaptomiden. Zool. Anz., 103(11-12): 295-304.

8. Brehm V., 1942. Über dei Diaptomiden und Pseudodiaptomiden der Zwischeneregion Wallacea. Int. Rev. ges. Hydrobiol. Hydrogr., 42(1-3): 269-287.

9. Brehm V., 1951. Cladocera und Copepoda Calanoida von Cambodja. Cybium, 6: 95124.

10. Brehm V., 1953. Indische diaptomiden, Pseudodiaptomiden und Cladoceren. Osterr. Zool., 4(3): 241-345.

11. Chang C.Y., 2009. Illustrated encyclopedia of fauna \& flora of Korea. Vol. 42. Inland water Copepoda. Ministry of Education, Science \& Engineering, Republic of Korea (Jeonghaeng-sa Publ. Co., Seoul), 687 pp.

12. Daday E., 1906. Untersuchungen über die Copepodenfauna von Hinterindien, Sumatra und Java, nebst einem Beitrag zur Copepoden kenntnis Hawaii. Inseln. Zool. Jb. Syst., 24(3), 175-206.

13. Defaye D., 2002. A new Tropodiaptomus (Copepoda, Calanoida, Diaptomidae, Diaptominae) from Vietnam. Crustaceana, 75(3/4): 341-350.

14. Dumont H. J., Reddy Y. R., 1993. A reappraisal of the genus Phyllodiaptomus Kiefer, 1936, with the description of $P$. wellekensae n. sp. from India, and a redescription of $P$. tunguidus Shen \& Tai, 1964 from China (Copepoda, Calanoida). Hydrobiologia, 263(2): 65-93. 
15. Dumont H. J., Reddy Y. R., 1994. Phyllodiaptomus praedictus n. sp. (Copepoda, Calanoida) from Thailand. Hydrobiologia, 273(2): 101-110.

16. Dumont H. J., Reddy Y. R., Sanoamuang L., 1996. Description of Phyllodiaptomus christineae n. sp. from Thailand, and distinction of two subgenera within Phyllodiaptomus Kiefer, 1936 (Copepoda, Calanoida). Hydrobiologia, 323(2): 139148.

17. Dussart B. H., Defaye D., 2002. World Directory of Crustacea Copepoda of Inland Waters. I - Calaniformes. Backhuys Publishers, Leiden, 276 pp.

18. Grochmalicki J., 1915. Beiträge zur Kenntnis der Süßwasserfauna Javas: Phyllopoda, Copepoda und Ostracoda. Bull. Acad. pol. sci. Cracovie, S. B: 217-242.

19. Ho Thanh Hai, Tran Duc Luong, Le Hung Anh, 2008. To add two species belonging to Diaptomidae family to the fauna of inland freshwater crustaceans (CalanoidaCopepoda) of Vietnam. Tap chi Sinh hoc, 30(3): 27-32 (in Vietnamese with English summary).

20. Kiefer F., 1974. Eine neue Diaptomidenart aus Malaysia (Crustacea: Copepoda: Calanoida). Zool. Anz., 192(5/6): 420-424.

21. Kiefer F., 1982 . Vergleichende Untersuchungen über Morphologie,

Taxonomie und geographische Verbreitung der Arten der Gattung Tropodiaptomus Kiefer (Copepoda: Calanoida) aus asiatischen Binnengewässern. Hydrobiologia, 93(3): 223-253.

22. Lai H. C., 1986. The freshwater Calanoida (Crustacea, Copepoda) of Indonesia. IndoMalayan Zool., 3(1): 39-61.

23. Lai H. C., Fernando C. H., 1978 a. Redescription of Neodiaptomus botulifer Kiefer and one of its related species. Hydrobiologia, 59(3): 229-235.

24. Lai H. C., Fernando C. H., 1978b. The Freshwater Calanoida (Crustacea: Copepoda) of Singapore and Peninsular Malaysia. Hydrobiologia, 6(2): 113-127.
25. Lai H. C., Fernando C. H., 1979. The Malaysian Tropodiaptomus (Copepoda: Calanoida) and its distribution. Hydrobiologia, 65(1): 75-81.

26. Lai H. C., Fernando C. H., 1980. Zoogeographical distribution of Southeast Asian freshwater Calanoida. Hydrobiologia, 74(1): 53-66.

27. Lai H. C., Fernando C. H., 1981. The freshwater Calanoida (Crustacea: Copepoda) of Thailand. Hydrobiologia, 76(1): 161-178.

28. Lai H. C., Mamaril A., Fernando C. H., 1979. The freshwater Calanoida (Crustacea: Copepoda) of the Philippines. Crustaceana, 37(3): 225-240.

29. Lim R. P., Fernando C. H., 1985. Areview of Malaysian freshwater Copepoda with notes on new records and little known species. Hydrobiologia, 128(1): 71-89.

30. Tran Duc Luong, 2012. Nghien cuu Giap xac chan cheo (Copepoda) va Trung banh xe (Rotifera) o cac thuy vuc nuoc ngot noi dia Viet Nam, unpubl., PhD. thesis, Vietnam Academy of Science and Technology, 158 pp. (in Vietnamese).

31. Reddy R. Y., 1987. A taxonomic revision of the genus Allodiaptomus Kiefer (Copepoda, Calanoida), including the description of a new species from India. Crustaceana, 52(2): 113-134.

32. Reddy R. Y., 1994. Copepoda: Calanoida: Diaptomidae. Key to the genera Heliodiaptomus, Allodiaptomus, Neodiaptomus, Phyllodiaptomus, Eodiaptomus, Arctodiaptomus and Sinodiaptomus. In: Dumont H. J. F. (ed.) Guides to the Identification of the Microinvertebrates of the Continental Waters of the World 5. SPB Academic Publishing, the Hague, 221 pp.

33. Reddy Y. R., Dumont H. J., 1999. Redescription of Heliodiaptomus elegans Kiefer, 1935, a rare south-east Asian calanoid copepod. Hydrobiologia, 394(0): 145-152.

34. Reddy Y. R., Sanoamuang L., Dumont J. 
H., 1998. A note on the Diaptomidae of Thailand, including redescription of three species and description of a new species (Copepoda, Calanoida). Hydrobiologia, 361(1): 201-223.

35. Reddy Y. R., Sanoamuang L., Dumont H. J., 2000. Amended delimitation of Mongolodiaptomus against Neodiaptomus and Allodiaptomus and redescription of the little known Mongolodiaptomus иenoi (Kikuchi, 1936) from Thailand (Copepoda: Calanoida: Diaptomidae). Hydrobiologia, 418(1): 99-109.

36. Rizo E. Z. C., Pascual J. A. F., Dy D. J. B., Labicane L. J. A., Trinidad C. B., Papa R. D. S., 2015. New records of an Invasive Calanoid Copepod, Arctodiaptomus dorsalis (Marsh, 1907) in freshwater ecosystems in the Bicol Peninsula (Luzon Is., Philippines). Phil. Sci. Tech., 8(1): 27-30.

37. Sanoamuang L., 1999. Species composition and distribution of freshwater Calanoida and Cyclopoida (Copepoda) of north-east Thailand. In: Schram F. R. \& Klein J. C. V. (eds.) Crustaceans and Biodiversity Crisis, Brill Academic Publishers, Leiden, I: 217230.

38. Sanoamuang L., 2001a. Distributions of three Eodiaptomus species (Copepoda: Calanoida) in Thailand, with a redescription of E. draconisignivomi Brehm, 1952. Hydrobiologia, 453/454(1): 565-576.

39. Sanoamuang L., 2001b. Eodiaptomus phuphanensis n. sp., a new freshwater copepod (Calanoida: Diaptomidae) from the Phu Phan National Park, Thailand. Int. Rev. Hydrobiol., 86(2): 219-228.

40. Sanoamuang L., 2001c. Mongolodiaptomus dumonti n. sp., a new freshwater copepod (Calanoida, Diaptomidae) from Thailand. Hydrobiologia, 448(1): 41-52.

41. Sanoamuang L., Athibai S., 2002. A new species of Neodiaptomus (Copepoda, Diaptomidae) from temporary waters in northeast Thailand. Hydrobiologia, 489(1): 71-82.

42. Sanoamuang L., Sivongxay N., 2004.
Description of Eodiaptomus phuvongi n. sp. (Copepoda, Calanoida) from Thailand and Laos. Crustaceana, 77(10): 1223-1236.

43. Sanoamuang L., Teeramaethee J., 2006. Phyllodiaptomus thailandicus, a new freshwater copepod (Copepoda, Calanoida, Diaptomidae) from Thailand. Crustaceana, 79(4): 475-487.

44. Sanoamuang L., Yindee W., 2001. A new species of Phyllodiaptomus (Copepoda, Diaptomidae) from northeast Thailand. Crustaceana, 74(5): 435-448.

45. Shen C. J., Song D. X., 1979. Calanoida. In: Shen C. J. and Fauna Editorial Committee (eds.) Freshwater Copepoda. Fauna Sinica, Crustacea. Science Press, Beijing, pp. 53163 (in Chinese).

46. Shen C. J., Tai A. Y., 1962. The copepoda of the Wu-li lake, Wu-sih, Kiangsu province. I. Calanoida. Acta Zool. Sinica, 14(1): 99-118 (in Chinese with English summary).

47. Shen C. J., Tai A. Y., 1964a. Descriptions of eight new species of freshwater Copepoda (Calanoida) from delta of the Pearl river, South China. Acta Zool. Sinica, 16(2): 225-246 (in Chinese with English summary).

48. Shen C. J., Tai A. Y., 1964b. Copepoda of Hsi-Song-Pang-Na Tai autonomous county and vicinity, Yannan province. Acta Zool. Sinica, 16(3): 440-463 (in Chinese with English summary).

49. Shen C. J., Tai A. Y., 1965. Descriptions of six new species of freshwater Copepods chiefly from the pearl river delta, South China. Acta Zootaxon. Sinica, 2(2): 126140 (in Chinese with English summary).

50. Dang Ngọc Thanh, 1977. New diaptomid crustacean from Vietnam. Tap chi Sinh vatDia hoc, XV(4): 97-99 (in Vietnamese with English summary).

51. Dang Ngoc Thanh, Thai Tran Bai, Pham Van Mien, 1980. Dinh loai dong vat khong xuong song nuoc ngot bac Viet Nam. Science and Technics Publishing House, 573 pp. (in Vietnamese). 
52. Dang Ngoc Thanh, Ho Thanh Hai, 1985. Two new diaptomid crustacean (CalanoidaDiaptomidae) from freshwater of south Vietnam. Tap chi Sinh hoc, 7(3): 40-44 (in Vietnamese with English summary).

53. Dang Ngoc Thanh, Ho Thanh Hai, 1991. Phyllodiatomus tunguidus - a diaptomid crustacean species newly revealed from Hoabinh reservoir, North Vienam. Tap chi Sinh hoc, 13(2): 31-32 (in Vietnamese with English summary).

54. Dang Ngoc Thanh, Ho Thanh Hai, 1994. A new diaptomid crustacean species from freshwaters of South Vietnam. Tap chi Sinh hoc, 16(3): 18-20 (in Vietnamese with English summary).

55. Dang Ngoc Thanh, Ho Thanh Hai, 1998. Review on the taxonomy and geographical distribution of two species of Diaptomidae crustaceans (Copepoda-Calanoida) from freshwaters of Vietnam. Tap chi Sinh hoc, 20(2): 1-6 (in Vietnamese with English summary).

56. Dang Ngoc Thanh, Ho Thanh Hai, 2001a.
Fauna of Vietnam 5. Freshwater crustacean of Vietnam. Science and Technics Publishing House, 464 pp (in Vietnamese).

57. Dang Ngoc Thanh, Ho Thanh Hai, 2001b. Two new crustacean species of Diaptomidae found in the river section inside of the Phongnha cave, Quang Binh province, Vietnam. Tap chi Sinh hoc, 23(4): 1-5 (in Vietnamese with English summary).

58. Dang Ngoc Thanh, Ho Thanh Hai, 2002. On the generic affinity and distribution of three little known freshwater diaptomid copepods (Crustacea, Copepoda-Calanoida) in South East Asia. Advances in Natural Sciences, 3(3): 273-280.

59. Dang Ngoc Thanh, Pham Van Mien, 1979. Contribution to the study of freshwater zooplankton of south Vietnam. Tap chi Sinh hoc, 1(4): 1-6 (in Vietnamese with English summary).

60. Tuyor J. B., Baay M. O., 2001. Contribution to the knowledge of freshwater Copepoda of the Philippines. Asia Life Sci., 10(1): 35-43.

\title{
DANH MƯC CHÚ GIẢI HỌ Diaptomidae Sars, 1903 (Calanoida, Copepoda) Ở CÁC THỦY VỰC NƯớC NGQ̣T NộI ĐỊA VIỆT NAM
}

\author{
Trần Đức Lương, Đặng Ngọc Thanh, Hồ Thanh Hải
}

Viện Sinh thái và Tài nguyên sinh vật, Viện Hàn lâm KH \& CN Việt Nam

\section{TÓM TÁ́T}

Bài báo này dựa trên các tài liệu đã được công bố và các số liệu phân tích từ các mẫu vật được lưu giữ tại Viện Sinh thái và Tài nguyên sinh vật (IEBR). Thông tin về phân loại học và phân bố của các loài giáp xác chân chèo nước ngọt trong họ Diaptomidae ở Việt Nam được cập nhật và tu chỉnh. Đến nay, tổng số có 13 giống với 29 loài đã được ghi nhận, đây là danh mục đầy đủ nhất với phân bố của tất cả các loài trong họ Diaptomidae ở Việt Nam. Trong số đó, 8 loài là đặc hữu cho Việt Nam; 7 loài đã được thay đổi về danh pháp và vị trí phân loại; 8 loài được bổ sung vào danh lục họ Diaptomidae công bố gần đây nhất năm 2001.

Tù khóa: Diaptomidae, Giáp xác chân chèo nước ngọt, Việt Nam.

Received 14 July 2016, accepted 20 September 2016 